\title{
Islam, Democracy and Political Leadership in Surakarta Municipal
}

\author{
Muhammad Adnan ${ }^{1}$, Wahid Abdulrahman ${ }^{2}$, Budi Setyono ${ }^{3}$ \\ \{adonan.sensei@gmail.com ${ }^{1}$ \} \\ Universitas Diponegoro, Indonesia ${ }^{1,2,3}$
}

\begin{abstract}
The relationship between Islam and democracy has been always fascinating to research in the middle of various views among Muslims regarding the issue. In Indonesia, the relationship is getting strong after the regional and general elections during 2017-2019. Surakarta municipal is a multicultural region yet has strong Islam organization dynamics that are being led by a non-moslem major. Using the qualitative method with an in-depth interview with Islamic organizations activists as a datagathering technique. this research is aimed to understand Islamic activists' points of view to democracy and political leadership in Surakarta. The results have shown that there are to main views of democracy. First, democracy is along the way to Islamic values and could be the fittest political system that can be applied in Indonesia. second, democracy is not the best system in Indonesia. Khilafah is thought to be the best system to replace democracy. Regarding political leadership in Surakarta, the major has given freedom to express faith for any religion. Nevertheless, for some groups, political leadership has been considered to be not committed enough to fight for Muslim community interests that were shown by a commitment to alcohol regulation, the house of worship and places to sell non-halal food establishment. These views are followed by the principle that a major should be from Muslim.
\end{abstract}

Keywords: Islam, Democracy, and Political Leadership.

\section{Introduction}

The development of democracy in Indonesia through the process of the election turned out to not fully run with the good quality of democracy. The ethnic, religion, race, and intergroup (SARA) issues escalate sharply especially on the religious dimension which again Islam became the mainframe. The emergence of religious sentiment in the selection process of public officials both by votes from the people and appointed originated from an understanding of the concept of Muslim leadership or the presence of leaders from non-Muslim circles.

The Surakarta municipal is a city with a diversity of people both in social and religious aspects. In the Islamic perspective, Surakarta municipal is a reflection of regions with heterogeneity in which there are various Islamic groups/organizations such as NU, Muhammadiyah, Al-Qur'an Tafsir Majlis (MTA), Surakarta Islamic Community Laskar (LUIS), Islamic Defenders Front (FPI) and others. The understanding of Islamic groups towards democracy will be followed by various movements which then influence regional policies. Amid the heterogeneity of society and the dynamics of the Islamic movement in the Surakarta municipal is currently led by the Mayor who is Christian. For this reason, this article is compiled based on research with a qualitative approach with primary data from interviews 
with activists or administrators of Islamic organizations in the city of Surakarta, namely: Surakarta municipal Syariah Board (Dewan Syariah Kota Surakarta), Surakarta Mosque Activist Communication Forum (Forum Komunikasi Aktivis Masjid Surakarta), GP Ansor, Islamic Student Association (HMI), Surakarta Islamic Community Laskar (Laskar Umat Islam Surakarta/LUIS), Indonesian Islamic Da'wah Institute (Lembaga Dakwah Islam Indonesia), Majlis Tafsir Al Quran, Muhammadiyah, and Islamic Cleric Council (Majlis Ulama Indonesia).

\section{Discussion}

The relationship between Islam and Democracy consists of at least two groups, the first is the group which considers that both are not mutually supportive or Islam is negative and incompatible with democracy. As Kedourie [1], says that the teachings, norms, tendencies, and daily experiences of Muslims have shaped the political views of Muslims that are unique and far from modern. Islamic civilization is unique in that Muslims are proud of their past heritage and are closed to the outside world. It is this civilization which, according to him, prevents Muslims from learning and appreciating the political and social progress achieved by other civilizations.

While, Lewis [2] argues that all aspects of Muslim life, including politics, are governed by God's law (shari'a), therefore, secularism as an important factor in modern social and political life cannot emerge from Muslim society.

Likewise according to Huntington [3], if Muslims try to introduce democracy into their societies, these efforts are likely to fail because Islam, which is very influential in their lives, does not support democracy. The failure of democracy in Muslim countries is partly due to the cultural character and Islamic society which is not friendly to the concept of western liberalism.

The second group is the view that assesses that Islam and democracy have a mutually supportive or positive relationship. As Hefner, Abdillah, Effendy [4][5][6] considered that Muslims, in general, have a positive attitude towards democracy. Likewise, Ramage (1995) specifically looks at conditions in Indonesia where traditional Muslims have a strong loyalty to democracy and tolerance.

From a broader perspective, the idea of the interaction between Islam and politics as AnNa'im's stated that between Islam and the State may be separated, but Islam and politics should not be separated. Islam and the current state and so on must be separated. But Islam and politics cannot and should not be separated [7][8]. This is what came to be called the interactive relationship between Islam and politics. The interactive relationship between Islam and politics is a condition in which Islamic forces can play their role in the political sphere through a series of policies produced.

This theory wants to break the deadlock about the theory of Islam and the State which during this time in a position facing each other often experience a dead end. According to AnNa'im, so far there have been two ideologically seen relations between Islam and the state. First, is the view that sees that Islam should not be separated from the state. Islam must be involved within and Islamic values, not only color but also become a reference for state policy. The theory requires that Islamic / sharia law must be a positive law of the state. And this is the view of the Islamists. Second, the view that sees Islam and the state must be 
separated institutionally. This means that there is religious neutrality from the state. This is the view of the secularists.

\subsection{Islam dan Democracy}

As a city with a heterogeneous population and have high dynamics Islamic organizations movement, while at the same time led by a Christian mayor, the perspective and relationship between Islamic organizations towards democracy and political leadership in Surakarta becomes interesting to illustrate.

From the perspective of activists or administrators of Islamic organizations in the Surakarta municipal, there are two views on the democratic system implemented in Indonesia. First and the majority view is that democracy is the right system to be implemented in Indonesia. Democracy is considered to have values that are in line with values in Islam including deliberation, justice, and involvement of citizens in policymaking. Ethnic and religious diversity is seen as a factor that increasingly places democracy as an appropriate system in addition to the existence of a control mechanism control overpower.

Nevertheless, in democracy practice in Indonesia is considered to have weaknesses including the increasingly fading principles of deliberation and unlimited freedom in expressing aspirations without being accompanied by ethics.

Second, the view that democracy is not the most appropriate system. Administrators of Islamic organizations that have such views consider that the Khilafah is a solution to the system and form of the state. The Khilafah is considered as the most appropriate form to be applied where the reason departs from an understanding of history from the time of Prophet Muhammad to the collapse of the Ottoman Turkish system that applied the caliphate. The Caliphate is considered as a form and system that can unite all Muslims. To those such organizations, Surakarta Municipal government still let them to do their activities.

\subsection{Political leadership in the Surakarta Municipal}

All Islamic organization activists in Surakarta acknowledge that the leadership of the mayor has been able to guarantee freedom and justice in religious life. Likewise, the ability to build a harmonious religious life is supported by the existence of the Interfaith Harmony Forum (FKUB)

In the perspective of Muslims interests, the leadership of the mayor was also considered accommodative to the activities of the Muslims, not only in commemoration of Islamic holidays but also the construction of worship facilities including the construction of the, once simple, now magnificent city hall mosque, and also want to build a mosque in Sriwedari. Under the Mayor's leadership, Solo positioned itself as "Sholawat City" which is a city full of Sholawat activities as in the Mayor's remarks to "Solo Bersholawat" on September 27, 2019, which was also attended by the Governor and Deputy Governor of Central Java.

Likewise, in the case of local government policies which were assumed to be no policy discrimination against any religion. All religious organizations have the same opportunity in accessing regional government facilities, including fun sourced from the regional budget and income.

However, in a regulatory perspective, some Islamic organizations consider that the Mayor's leadership has not been able to fight for the demands of the people in upholding Islamic teachings in accordance with the authority of the local government, namely about liquor, and ignorance to the practice of buying and selling non-halal food (food that comes 
from dogs and pigs). The demand to issue regional regulations governing liquor and regulating the practice of selling food from dog meat and pork, that is increasingly widespread, has not been able to be made by the local government.

\section{Conclusion}

There are two views of the administrators of Islamic organizations in the Surakarta municipal towards democracy. The first view is that democracy has conformity with Islamic values and is the best system for Indonesia despite various weaknesses in practice. The second view considers that democracy is not the best system. Instead, the Khilafah is considered to be the best system that must be upheld at least from the background of Islamic history.

Political leadership in the Surakarta municipal with the Christian Mayor has been able to realize a harmonious interfaith life, fair policies, and accommodating towards the activities of Muslims. However, some consider that the existing leadership has not been able to fight for the interests of Muslims, especially relating to the regulations governing liquor and the practice of selling food from dog meat and pork that is increasingly widespread.

\section{References}

[1] K. Elie, Politics in the Middle East. Oxford University, 1994.

[2] B. Lewis, What went wrong?: Western impact and Middle Eastern response. Oxford University Press, 2002.

[3] S. P. Huntington, "The Clash of Civilizations and the Remaking of World Order. 1996," Polish Ed. MUZA SA, 1997.

[4] R. W. Hefner, Civil islam: Muslims and democratization in indonesia, vol. 40. Princeton University Press, 2011.

[5] M. Abdillah and W. Wahab, Demokrasi di persimpangan makna: respons intelektual muslim Indonesia terhadap konsep demokrasi (1966-1993). PT Tiara Wacana, 1999.

[6] B. Effendy, Islam dan Negara: Transformasi Pemikiran dan Praktek Politik Islam di Indonesia. Jakarta, 1998.

[7] A. A. A. Naim, A. A. An-Náim, and A. A. An-Na'im Na, Islam and the secular state. Harvard University Press, 2008.

[8] M. Zulifan, "Politik Islam di Indonesia: Ideologi, Transformasi dan Prospek dalam Proses Politik Terkini," Polit. Indones. Indones. Polit. Sci. Rev., vol. 1, no. 2, pp. 171-195, 2016. 